\title{
Immunoexpression of cyclooxygenase-1 and -2 in ulcerative colitis
}

A.P.R. Paiotti ${ }^{1}$, R. Artigiani Neto ${ }^{1}$, N.M. Forones ${ }^{2}$, C.T.F. Oshima ${ }^{1}$, S.J. Miszputen ${ }^{2}$ and M. Franco ${ }^{1}$

\author{
${ }^{1}$ Departamento de Patologia, ${ }^{2}$ Disciplina de Gastroenterologia, \\ Escola Paulista de Medicina, Universidade Federal de São Paulo, São Paulo, \\ SP, Brasil
}

\begin{abstract}
Correspondence
M. Franco

Departamento de Patologia EPM, UNIFESP

Rua Botucatu, 740, $1^{\circ}$ andar

04023-900 São Paulo, SP

Brasil

Fax: +55-11-5571-9295

E-mail: mfranco@patologia.epm.br

Research supported by FAPESP.

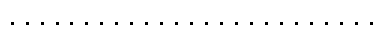

Received August 17, 2006

Accepted May 11, 2007

\section{Abstract}

Ulcerative colitis (UC) is a disease of the colon and rectum characterized by a nonspecific chronic inflammation mediated by the concerted response of cellular and humoral events. Prostaglandins are synthesized by cyclooxygenase (COX)- 1 and -2 and exhibit both pro- and anti-inflammatory activity. To evaluate COX-1 and COX-2 immunoexpression in 42 cases of UC and to correlate it with clinicopathological parameters, $\mathrm{COX}-1$ and COX-2 expression was investigated by the immunohistochemistry method. Only patients with all pertinent clinical and evolutive data as well as with adequate biopsy material were included in the study. Fifteen samples of colorectal adenocarcinoma and 14 of large bowel with no histological changes were used for positive and negative controls, respectively. UC patients showed COX-1 immunoreactivity in epithelial cells in $29 \%$ of the cases and in inflammatory cells in $43 \%$. COX-2 positivity in epithelial and inflammatory cells was found in $69 \%$ of the samples. The comparison between UC and the control groups revealed that the UC group had significantly more positive cases for COX-1 and COX-2 in inflammatory cells. Immunohistochemistry allowed the identification of COX1 and COX-2 expression in epithelial and inflammatory cells in UC biopsies. No significant difference between COX-1 and COX-2 immunoreactivity in epithelial and inflammatory cells was observed regarding the clinicopathological parameters. COX-2 presented low expression in normal colon and high expression in colorectal adenocarcinoma. COX-2 might play a role in the pathophysiologic processes of inflammatory bowel disease and the development of neoplasia. Treatment with selective COX-2 inhibitors might be an additional option for therapy.

\section{Introduction}

Ulcerative colitis (UC), which belongs to the spectrum of inflammatory bowel disease (IBD), is a disease of the colon and rectum of unknown etiology which is characterized by
Key words

- Ulcerative colitis

- Cyclooxygenases

- Prostaglandins

- Immunohistochemistry 
lites that are collectively referred to as eicosanoids. PGs are produced via the cyclooxygenase (COX) pathway and exhibit both pro- and anti-inflammatory effects (2). COX is now known to exist in three isoforms: COX-1, COX-2, and COX-3. COX-1 is a constitutively expressed 66-kDa enzyme, showing low or no expression in a variety of tissues $(3,4)$ including the intestine and colon (2). The COX-1 gene is considered to be a housekeeping gene and is believed to maintain the cell integrity of the gastrointestinal tract $(2,5)$, the regulation of blood flow through the kidneys, and platelet aggregation (6). COX-2 is an interferon- $\gamma$-induced $70-\mathrm{kDa}$ enzyme which presents $61 \%$ homology to COX-1 (7). The enzyme is induced in response to cellular activation mediated by hormones, pro-inflammatory cytokines and growth factors. It is an important mediator of the inflammatory process $(2,5)$ and carcinogenesis, as well as in the progression of a newly developed carcinoma $(8,9)$. COX-3, possibly a variant of COX-1 since it is derived from the same gene, has been demonstrated in vitro in macrophage cell lines, and is mainly found in the cerebral cortex, spinal cord and heart $(10,11)$.

There are markedly elevated levels of PGs in the mucosa and rectal dialysates from IBD patients (12). The increased release of $\mathrm{PGE}_{2}$ observed in UC may therefore originate from a relatively small number of recruited inflammatory cells (13). The cellular origin of these PGs and the relative contributions of COX-1 and COX-2 to their production have not been fully investigated.

The objectives of the present study were to analyze the immunoexpression of $\mathrm{COX}-1$ and COX-2 proteins in biopsies from UC patients and to correlate it with histopathological parameters and clinical follow-up.

\section{Patients and Methods}

Biopsies from the files of the Department of Pathology, obtained from 42 consecutive patients with UC seen at the Inflammatory Bowel Disease Clinic of the Gastroenterology Division, Paulista Medical School, São Paulo Federal University, were studied. Only patients with all pertinent clinical and evolutive data as well as with adequate biopsy material were included in the study. Patient characteristics, including gender, age, disease extension, and clinical activity were obtained from the medical records. All procedures were approved by the Ethics Committee of the Institution. Fifteen samples of colorectal adenocarcinoma and 14 of large bowel with no histological changes were randomly selected for positive and negative controls, respectively.

\section{Histopathological analysis}

Three-micrometer thick sections of each block stained with hematoxylin-eosin were reviewed independently by two pathologists. The following parameters were analyzed: presence (+) or absence (-) of edema, erosion/ulceration, crypt abscesses, lymphoid aggregates, lamina propria lymphoplasmocytosis, mucin depletion, and Paneth cell metaplasia; presence (1-3+) or absence (-) of acute inflammation in the lamina propria, where $1+=$ focal crypt epithelial polymorphs, $2+=$ diffuse crypt epithelial polymorphs, and $3+=$ polymorph exudate; presence (1$3+)$ or absence (-) of architectural distortion, where $1+=$ focal crypt architectural irregularity, $2+=$ diffuse crypt architectural irregularity, and $3+=$ mucosal atrophy.

\section{Immunohistochemical analysis}

Immunohistochemistry for COX-1 (Cayman Chemical Co., Ann Arbor, MI, USA, Cat. No. 160110) and COX-2 (Cayman Chemical Co., Cat. No. 160112) was carried out according to manufacturer instructions using the labeled streptavidin-biotin-peroxidase complex system (Dako, Carpinteria, CA, USA). The tissues were incubated with 
commercial monoclonal antibodies diluted 1:120 (COX-1) and 1:100 (COX-2) after microwave antigen retrieval $(20 \mathrm{~min}$ in citrate buffer, $\mathrm{pH}$ 6.0). Sections known to express high levels of COX-1 and COX-2 were included as positive controls, while negative control slides omitted the primary antibody.

\section{Evaluation of staining}

Evaluation of COX-1 and COX-2 reactivity was performed according to a previously described scoring system (14) with staining intensity graded as 1 (weak), 2 (moderate), or 3 (strong), and the positively stained area as 0 $(<10 \%), 1(10-40 \%), 2(40-70 \%)$, and 3 $(\geq 70 \%)$. Both parameters were evaluated in the cytoplasm of epithelial and inflammatory cells. Total scores for grade and area classified as $\geq 3$ were defined as positive expression and those classified as $<3$ as negative.

\section{Statistical analysis}

Data are reported as means $\pm \mathrm{SD}$. The chisquare test and Fisher's exact probability test, where appropriate, were used to correlate the immunoexpression of COX-1 and COX-2 with the clinicopathological parameters. The Kruskal-Wallis test was used for comparison between the UC and control groups. A P value $<0.05$ was considered statistically significant.

\section{Results}

\section{Socio-demographic and clinical-evolutive variables}

Among the 42 UC patients, 55\% were females and $57 \%$ Caucasians. Mean age at diagnosis was $42.0 \pm 15.1$ years, and mean disease duration was $5.0 \pm 6.4$ years. Regarding disease extension, $40 \%$ of the patients had proctosigmoiditis, $43 \%$ pancolitis and $17 \%$ left-sided colitis. According to Truelove and Witt's (15) clinical activity score, activity was mild in $64 \%$ of the patients, moderate in $7 \%$ and severe in $17 \%$.

\section{Histopathological findings}

Edema and architectural distortion were present in all samples (1+: 22\%, 2+: 45\%, $3+: 33 \%)$. Erosion/ulceration was observed in $81 \%$ of the samples, acute inflammation in $93 \%$ (1+: 17\%, 2+: 43\%, 3+: 33\%), crypt abscesses in $74 \%$, lymphoid aggregates in $50 \%$, and lamina propria lymphoplasmocytosis in $83 \%$. Paneth cell metaplasia was identified in $24 \%$ of cases, and mucin depletion in $38 \%$.

\section{Immunohistochemistry}

COX-1 immunoreactivity was positive in epithelial cells in $29 \%$ of cases, both at the surface and in the crypts, and in inflammatory cells in $43 \%$ of cases. COX-2 positivity in epithelial (crypts and surface) and inflammatory cells were found in $69 \%$ of the patients. The immunolocalization of the proteins was cytoplasmic and the reactive inflammatory immunopositive cells were mononuclear cells and leukocytes.

The correlation between positive and negative COX-1 and COX-2 cellular immunoreactivity and the clinicopathological parameters analyzed showed no significant differences ( $P>0.05$; Tables 1 and 2$)$.

Comparison of the immunohistochemical pattern between the control, UC and colorectal adenocarcinoma groups was shown in Figure 1.

No significant correlation was observed between the three groups regarding the distribution of COX-1 and COX-2 immunoreactivity in epithelial, mucosal and carcinomatous cells ( $\mathrm{P}>0.05$ for all comparisons). The inflammatory cells showed a significant difference between groups regarding the distribution of COX-1 and COX-2 immunoreactivity $(\mathrm{P}=0.002, \mathrm{P}<0.001$, respectively), with significantly higher positive cases in the UC group (Figure 2). 


\begin{tabular}{|c|c|c|c|c|}
\hline \multirow[t]{2}{*}{ Variables } & \multicolumn{2}{|c|}{ COX-1 positive } & \multicolumn{2}{|c|}{ COX-2 positive } \\
\hline & Epithelium & Infiltrate & Epithelium & Infiltrate \\
\hline \multicolumn{5}{|l|}{ Gender } \\
\hline Male & $6(50.0 \%)$ & $8(44.4 \%)$ & $14(48.3 \%)$ & $13(44.8 \%)$ \\
\hline Female & $6(50.0 \%)$ & $10(55.6 \%)$ & $15(51.7 \%)$ & $16(55.2 \%)$ \\
\hline \multicolumn{5}{|l|}{ Age (years) } \\
\hline $16-40$ & $6(50.0 \%)$ & $9(50.0 \%)$ & $11(62.0 \%)$ & $13(44.8 \%)$ \\
\hline 41-74 & $6(50.0 \%)$ & $9(50.0 \%)$ & $18(38.0 \%)$ & $16(55.2 \%)$ \\
\hline \multicolumn{5}{|l|}{ Race } \\
\hline White & $5(41.7 \%)$ & $9(50.0 \%)$ & $17(58.6 \%)$ & $15(51.7 \%)$ \\
\hline Non-white & $7(58.3 \%)$ & $9(50.0 \%)$ & $12(41.4 \%)$ & $14(48.3 \%)$ \\
\hline \multicolumn{5}{|c|}{ Disease evolution (years) } \\
\hline $0-10$ & $10(83.3 \%)$ & $14(77.8 \%)$ & $25(86.2 \%)$ & $24(82.8 \%)$ \\
\hline $11-22$ & $2(16.7 \%)$ & $4(22.2 \%)$ & $4(13.8 \%)$ & $5(17.2 \%)$ \\
\hline \multicolumn{5}{|l|}{ Disease extension } \\
\hline Proctosigmoiditis & $6(50.0 \%)$ & $9(50.0 \%)$ & $13(44.8 \%)$ & $14(48.3 \%)$ \\
\hline Left-sided colitis & $1(8.3 \%)$ & $2(11.1 \%)$ & $4(13.8 \%)$ & $4(13.8 \%)$ \\
\hline Pancolitis & $5(41.7 \%)$ & 7 (38.9\%) & $12(41.4 \%)$ & $11(37.9 \%)$ \\
\hline \multicolumn{5}{|l|}{ Clinical activity } \\
\hline Remission & $1(8.3 \%)$ & $2(11.1 \%)$ & $4(13.8 \%)$ & $4(13.8 \%)$ \\
\hline Mild & $5(41.7 \%)$ & $9(50.0 \%)$ & $19(65.5 \%)$ & $19(65.5 \%)$ \\
\hline Moderate & $2(16.7 \%)$ & $3(16.7 \%)$ & $2(6.9 \%)$ & $2(6.9 \%)$ \\
\hline Severe & $4(33.3 \%)$ & $4(22.2 \%)$ & $4(13.8 \%)$ & $4(13.8 \%)$ \\
\hline
\end{tabular}

Data are reported as number with percent in parentheses. $\mathrm{P}>0.05$ for all tests (chi-square and Fisher exact tests).

Table 2. Histopathological characteristics of ulcerative colitis patients with immunoexpression of cyclooxygenase-1 (COX-1) and -2 (COX-2).

\begin{tabular}{|c|c|c|c|c|}
\hline \multirow[t]{2}{*}{ Variables } & \multicolumn{2}{|c|}{ COX-1 positive } & \multicolumn{2}{|c|}{ COX-2 positive } \\
\hline & Epithelium & Infiltrate & Epithelium & Infiltrate \\
\hline \multicolumn{5}{|l|}{ Erosion/ulceration } \\
\hline Absent & $1(8.3 \%)$ & $1(5.6 \%)$ & $5(17.2 \%)$ & $5(17.2 \%)$ \\
\hline Present & $11(91.7 \%)$ & $17(94.4 \%)$ & $24(82.8 \%)$ & $24(82.8 \%)$ \\
\hline \multicolumn{5}{|l|}{ Acute inflammatory process } \\
\hline Absent & $0(0.0 \%)$ & $0(0.0 \%)$ & $2(6.9 \%)$ & $2(6.9 \%)$ \\
\hline Focal crypt epithelial polymorphs & $2(16.7 \%)$ & $2(11.2 \%)$ & $5(17.2 \%)$ & $5(17.2 \%)$ \\
\hline Diffuse crypt epithelial polymorphs & $6(50.0 \%)$ & $8(44.4 \%)$ & $11(37.9 \%)$ & $12(41.4 \%)$ \\
\hline Polymorph exudate & $4(33.3 \%)$ & $8(44.4 \%)$ & $11(37.9 \%)$ & $10(34.5 \%)$ \\
\hline \multicolumn{5}{|l|}{ Architectural distortion } \\
\hline Focal crypt architectural irregularity & $3(25.0 \%)$ & $3(16.7 \%)$ & $7(24.1 \%)$ & $7(24.1 \%)$ \\
\hline Diffuse crypt architectural irregularity & $6(50.0 \%)$ & $8(44.4 \%)$ & $12(41.4 \%)$ & $12(41.4 \%)$ \\
\hline Mucosal atrophy & $3(25.0 \%)$ & 7 (38.9\%) & $10(34.5 \%)$ & $10(34.5 \%)$ \\
\hline \multicolumn{5}{|l|}{ Crypt abscesses } \\
\hline Absent & $5(41.7 \%)$ & $6(33.3 \%)$ & $8(27.6 \%)$ & $9(31.0 \%)$ \\
\hline Present & $7(58.3 \%)$ & $12(66.7 \%)$ & $21(72.4 \%)$ & $20(69.0 \%)$ \\
\hline \multicolumn{5}{|l|}{ Lymphoid aggregates } \\
\hline Absent & $6(50.0 \%)$ & $9(50.0 \%)$ & $16(55.2 \%)$ & $17(58.6 \%)$ \\
\hline Present & $6(50.0 \%)$ & $9(50.0 \%)$ & $13(44.8 \%)$ & $12(41.4 \%)$ \\
\hline \multicolumn{5}{|l|}{ Paneth cell metaplasia } \\
\hline Absent & $10(83.3 \%)$ & $15(83.3 \%)$ & $22(75.9 \%)$ & $23(79.3 \%)$ \\
\hline Present & $2(16.7 \%)$ & $3(16.7 \%)$ & $7(24.1 \%)$ & $6(20.7 \%)$ \\
\hline \multicolumn{5}{|l|}{ Lamina propria lymphoplasmocytosis } \\
\hline Absent & $2(16.7 \%)$ & $2(11.1 \%)$ & $6(20.7 \%)$ & $6(20.7 \%)$ \\
\hline Present & 10 (83.3\%) & $16(88.9 \%)$ & $23(79.3 \%)$ & 23 (79.3\%) \\
\hline \multicolumn{5}{|l|}{ Mucin depletion } \\
\hline Absent & $6(50.0 \%)$ & $9(50.0 \%)$ & $16(55.2 \%)$ & $18(62.1 \%)$ \\
\hline Present & $6(50.0 \%)$ & $9(50.0 \%)$ & $13(44.8 \%)$ & 11 (37.9\%) \\
\hline
\end{tabular}

Data are reported as number with percent in parentheses. $\mathrm{P}>0.05$ for all tests (chi-square and Fisher exact tests). 

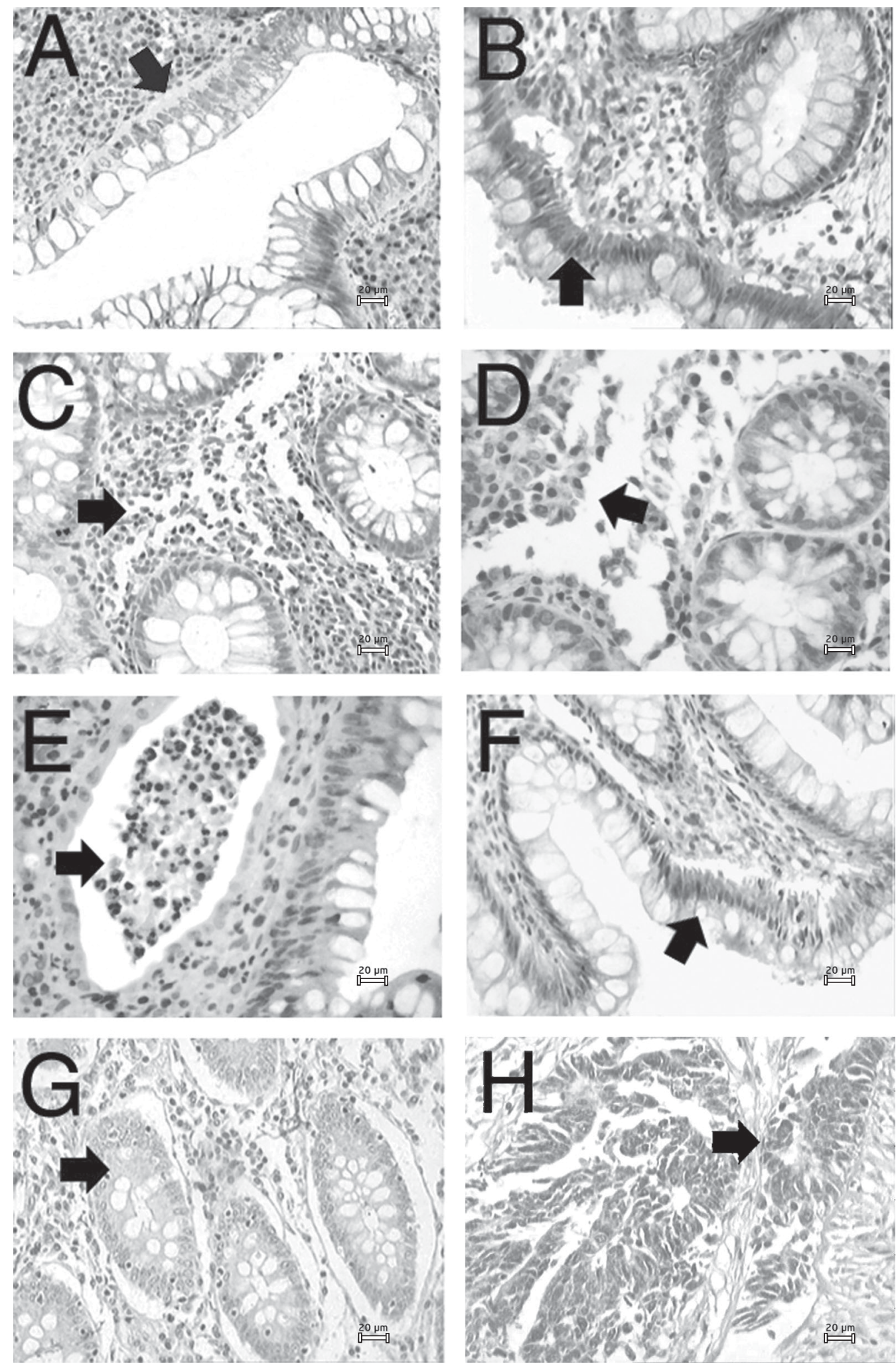
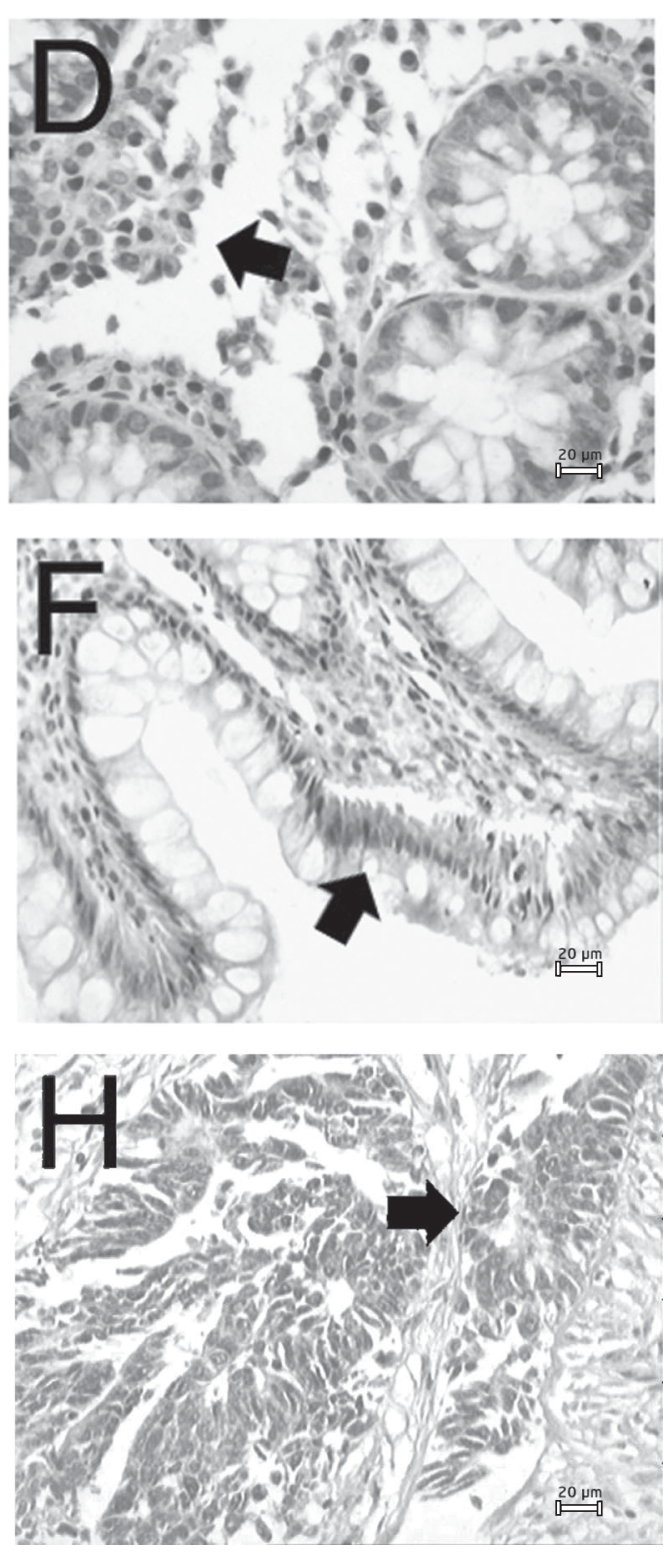

Figure 1. Comparison of the immunohistochemical pattern between the control, ulcerative colitis (UC) and colorectal carcinoma groups. Immunohistochemical profile of cyclooxygenase-2 (COX-2) in UC: the arrows indicate the cytoplasmic staining in epithelial cells $(A, B)$ and inflammatory cells $(C, D)$. Profile of cyclooxygenase-1 (COX-1) in UC: the arrows indicate the cytoplasmic staining of inflammatory cells in crypt abscesses (E) and epithelial cells (F). Profile of COX-1 in control group: the arrow indicates the cytoplasmic staining in epithelial cells (G). Profile of COX-2 in colorectal cancer: the arrow indicates the cytoplasmic staining in neoplastic epithelial cells $(\mathrm{H})$. Magnification $=200 \mathrm{X}$. Scale bar $=20 \mu \mathrm{m}$ for all panels. 


\section{Discussion}

Inflammation involves plasma-derived and cellular events normally occurring in response to tissue injury or infection. In chronic inflammation, the process continues due to the persistence of the injury and consequently of the inflammatory mediators. The focus on salicylates has led to studies on the arachidonic acid cascade and on COX and 5-lipoxygenase products. Clinical trials with non-steroidal anti-inflammatory drugs in IBD showed no effect or even a detrimental effect. This finding is in striking contrast to the efficiency of non-steroidal anti-inflammatory drugs in rheumatoid arthritis another autoimmune disease involving PGs - and it might be inferred that COX is of no relevance in IBD (16-19).

COX-2 was shown to be responsible for the increase in COX activity in inflammation; increased concentrations of COX-2 have been found in synovial tissue during attacks

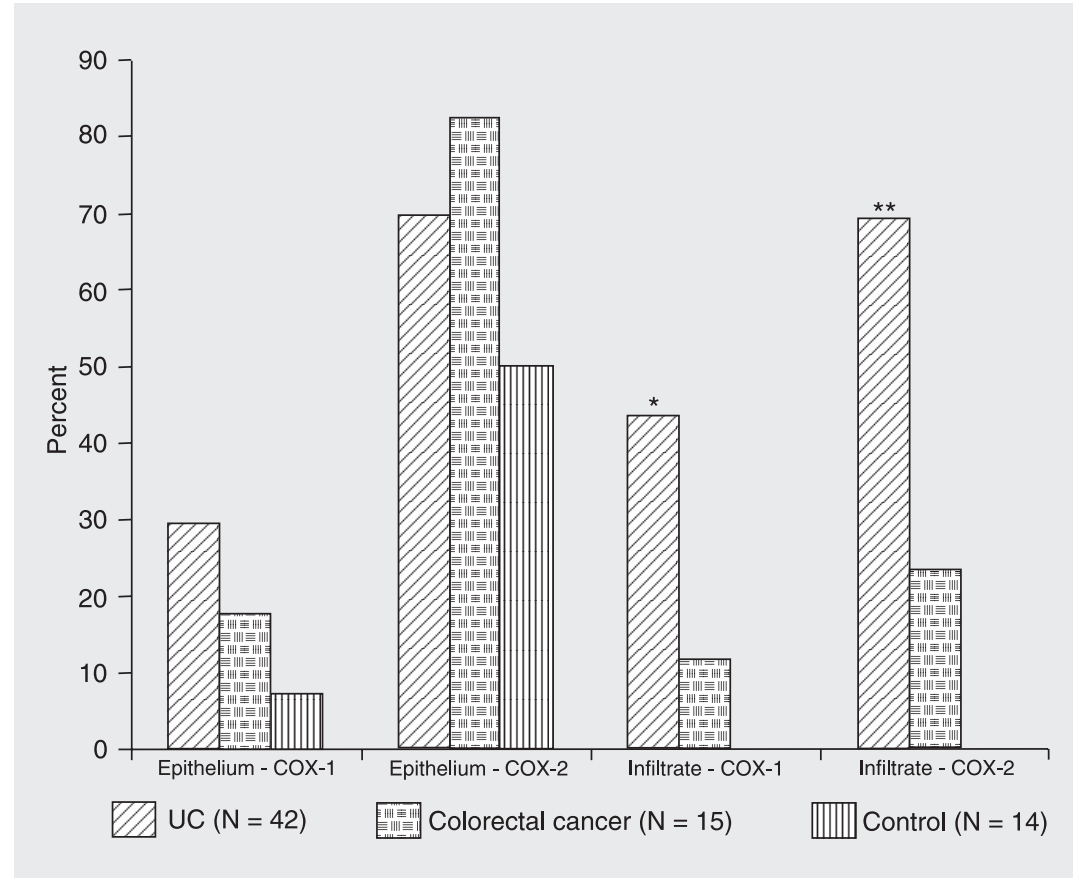

Figure 2. Comparison of the immunohistochemical results between ulcerative colitis (UC) and colorectal adenocarcinoma groups and control. The numbers in parentheses are the number of patients. ${ }^{*} \mathrm{P}=0.002$ and ${ }^{* *} \mathrm{P}<0.001$ for cyclooxygenase-1 (COX-1) and -2 (COX2), respectively, compared to colorectal adenocarcinoma groups (Kruskal-Wallis test). of rheumatoid arthritis (20). The discovery of COX-2 reopens the discussion about the importance of COX products in IBD. It has been shown that COX-1 and COX-2 exhibit differences in their sub-cellular localization and ability to metabolize arachidonic acid (21).

We found no significant correlation between positive and negative $\mathrm{COX}-1$ and COX-2 immunoreactivity in epithelial and inflammatory cells in cases of UC and clinicopathological parameters analyzed $(\mathrm{P}>$ $0.05)$. On the other hand, there were cases with crypt abscesses and lamina propria lymphoplasmocytosis with high COX-1 and COX-2 immunoreactivity.

To the best of our knowledge, no study has correlated cellular immunoexpression of COX-1 and COX-2 with the clinicopathological findings in IBD. However, Hendel and Nielsen (16), studying the expression of COX-2 mRNA in IBD, demonstrated a clear relationship between endoscopic activity and the relative presence of this expression.

In our series, epithelial cell immunoreactivity of COX-1 was detected in $29 \%$ of the UC patients and immunoreactivity in inflammatory cells in $43 \%$. However, low or no expression of COX-1 was observed in the control and cancer groups, a finding also reported by others $(4,5,11,22)$.

The immunoreactivity of COX-2 was observed in epithelial and inflammatory cells in $69 \%$ of patients with UC, indicating that this immunoreactivity is strongly induced not only in lamina propria cells but also in apical epithelial cells of the colonic mucosa in $\operatorname{IBD}(23,24)$. Analysis of the immunohistochemical results for the various groups showed a difference in the distribution of COX-1 and COX-2 in the inflammatory cells, with a higher proportion of positive cases in the UC group.

Concerning COX-2, investigators (2426) did not detect immunolabeling in normal epithelium. However, in the present series, COX-2 immunopositivity in epithelial cells 
was observed in $50 \%$ of the control cases, a fact also reported by Jackson et al. (27). Other studies have reported that COX-2 is constitutively expressed in a variety of tissues such as kidney, spine and eyes (28-30).

COX-2 was observed in epithelial cells of patients with UC, as well as of patients with colorectal carcinoma. Singer et al. (24), studying the immunoexpression of COX-1 and COX-2 in UC tissues, Crohn's disease and normal epithelium, observed greater immunolabeling of COX-2 in epithelial cells of UC and Crohn's disease samples, suggesting that the persistent expression of this protein might be related to an increased risk of carcinogenesis. In fact, large amounts of COX-2 have been demonstrated in pre-neoplastic tissues $(31,32)$ and in various carcinomas (33), reflecting the effects of oncogenes and growth factors which are known to be inducers of this enzyme $(34,35)$. In addition, Agoff et al. (36), using molecular biology and immunohistochemistry, ob- served that in UC associated with neoplasia over-expression of COX-2 was present in all stages of the neoplastic process.

As reported in other studies $(5,28)$, immunolabeling of this protein was also frequently observed in fibroblasts.

Based on the present study and on data of others $(37,38)$, we suggest that COX-1 is not an exclusively constitutive enzyme and similarly to COX-2, may have a role as a mediator of inflammation.

Our data demonstrate that immunohistochemistry permitted the identification of the COX-1 and COX-2 expression in epithelial and inflammatory cells of biopsies from UC patients. COX-2 showed low immunoexpression in normal colon and higher expression in colorectal adenocarcinoma. COX-2 may probably play a role in the pathophysiologic processes of inflammatory bowel disease and in the development of neoplasia. Treatment with selective COX-2 inhibitors might be an additional option for therapy.

\section{References}

1. Nielsen $\mathrm{OH}$, Rask-Madsen J. Mediators of inflammation in chronic inflammatory bowel disease. Scand J Gastroenterol Suppl 1996; 216: 149-159.

2. Eberhart CE, Dubois RN. Eicosanoids and the gastrointestinal tract. Gastroenterology 1995; 109: 285-301.

3. Deininger MH, Weller M, Streffer J, Mittelbronn M, Meyermann R. Patterns of cyclooxygenase-1 and -2 expression in human gliomas in vivo. Acta Neuropathol 1999; 98: 240-244.

4. Sano H, Kawahito Y, Wilder RL, Hashiramoto A, Mukai S, Asai K, et al. Expression of cyclooxygenase-1 and -2 in human colorectal cancer. Cancer Res 1995; 55: 3785-3789.

5. Mitchell JA, Larkin S, Williams TJ. Cyclooxygenase-2: regulation and relevance in inflammation. Biochem Pharmacol 1995; 50: 15351542.

6. Smith WL, Dewitt DL, Garavito RM. Cyclooxygenases: structural, cellular, and molecular biology. Annu Rev Biochem 2000; 69: 145182.

7. Vane JR, Bakhle YS, Botting RM. Cyclooxygenases 1 and 2. Annu Rev Pharmacol Toxicol 1998; 38: 97-120.

8. Ito $\mathrm{Y}$, Yoshida H, Nakano K, Takamura Y, Miya A, Kobayashi K, et al. Cyclooxygenase-2 expression in thyroid neoplasms. Histopathology 2003; 42: 492-497.

9. Koga H, Sakisaka S, Ohishi M, Kawaguchi T, Taniguchi E, Sasatomi $\mathrm{K}$, et al. Expression of cyclooxygenase-2 in human hepatocellular carcinoma: relevance to tumor dedifferentiation. Hepatology 1999;
29: 688-696.

10. Chandrasekharan NV, Dai H, Roos KL, Evanson NK, Tomsik J, Elton TS, et al. COX-3, a cyclooxygenase-1 variant inhibited by acetaminophen and other analgesic/antipyretic drugs: cloning, structure, and expression. Proc Natl Acad Sci U S A 2002; 99: 1392613931.

11. Colville-Nash PR, Qureshi SS, Willis D, Willoughby DA. Inhibition of inducible nitric oxide synthase by peroxisome proliferator-activated receptor agonists: correlation with induction of heme oxygenase $1 . J$ Immunol 1998; 161: 978-984.

12. Lauritsen K, Laursen LS, Bukhave K, Rask-Madsen J. Effects of topical 5-aminosalicylic acid and prednisolone on prostaglandin E2 and leukotriene B4 levels determined by equilibrium in vivo dialysis of rectum in relapsing ulcerative colitis. Gastroenterology 1986; 91 : 837-844.

13. Raab Y, Sundberg C, Hallgren R, Knutson L, Gerdin B. Mucosal synthesis and release of prostaglandin E2 from activated eosinophils and macrophages in ulcerative colitis. Am J Gastroenterol 1995; 90: 614-620.

14. Xiong B, Sun TJ, Hu WD, Cheng FL, Mao M, Zhou YF. Expression of cyclooxygenase-2 in colorectal cancer and its clinical significance. World J Gastroenterol 2005; 11: 1105-1108.

15. Truelove SC, Witts LJ. Cortisone in ulcerative colitis; final report on a therapeutic trial. Br Med J 1955; 2: 1041-1048.

16. Hendel J, Nielsen $\mathrm{OH}$. Expression of cyclooxygenase-2 mRNA in 
active inflammatory bowel disease. Am J Gastroenterol 1997; 92: 1170-1173.

17. Hanauer SB. Inflammatory bowel disease. N Engl J Med 1996; 334: 841-848.

18. Gaginella TS, Walsh RE. Sulfasalazine. Multiplicity of action. Dig Dis Sci 1992; 37: 801-812.

19. Hawkey CJ, Rampton DS. Benoxaprofen in the treatment of active ulcerative colitis. Prostaglandins Leukot Med 1983; 10: 405-409.

20. Crofford LJ, Wilder RL, Ristimaki AP, Sano H, Remmers EF, Epps $\mathrm{HR}$, et al. Cyclooxygenase-1 and -2 expression in rheumatoid synovial tissues. Effects of interleukin-1 beta, phorbol ester, and corticosteroids. J Clin Invest 1994; 93: 1095-1101.

21. Morita I, Schindler M, Regier MK, Otto JC, Hori T, Dewitt DL, et al. Different intracellular locations for prostaglandin endoperoxide $\mathrm{H}$ synthase-1 and -2. J Biol Chem 1995; 270: 10902-10908.

22. Borzacchiello G, Ambrosio V, Galati P, Perillo A, Roperto F. Cyclooxygenase-1 and -2 expression in urothelial carcinomas of the urinary bladder in cows. Vet Pathol 2003; 40: 455-459.

23. Tatsuguchi A, Sakamoto C, Wada K, Akamatsu T, Tsukui T, Miyake $\mathrm{K}$, et al. Localisation of cyclooxygenase 1 and cyclooxygenase 2 in Helicobacter pylori related gastritis and gastric ulcer tissues in humans. Gut 2000; 46: 782-789.

24. Singer II, Kawka DW, Schloemann S, Tessner T, Riehl T, Stenson WF. Cyclooxygenase 2 is induced in colonic epithelial cells in inflammatory bowel disease. Gastroenterology 1998; 115: 297-306.

25. Joo YE, Oh WT, Rew JS, Park CS, Choi SK, Kim SJ. Cyclooxygenase-2 expression is associated with well-differentiated and intestinal-type pathways in gastric carcinogenesis. Digestion 2002; 66: 222-229.

26. Joo YE, Rew JS, Seo YH, Choi SK, Kim YJ, Park CS, et al. Cyclooxygenase-2 overexpression correlates with vascular endothelial growth factor expression and tumor angiogenesis in gastric cancer. J Clin Gastroenterol 2003; 37: 28-33.

27. Jackson LM, Wu KC, Mahida YR, Jenkins D, Hawkey CJ. Cyclooxygenase (COX) 1 and 2 in normal, inflamed, and ulcerated human gastric mucosa. Gut 2000; 47: 762-770.

28. Harris RC, McKanna JA, Akai Y, Jacobson HR, Dubois RN, Breyer
MD. Cyclooxygenase-2 is associated with the macula densa of rat kidney and increases with salt restriction. J Clin Invest 1994; 94: 2504-2510.

29. Maihofner C, Schlotzer-Schrehardt U, Guhring H, Zeilhofer HU, Naumann GO, Pahl A, et al. Expression of cyclooxygenase-1 and -2 in normal and glaucomatous human eyes. Invest Ophthalmol Vis Sci 2001; 42: 2616-2624.

30. Maihofner C, Tegeder I, Euchenhofer C, deWitt D, Brune K, Bang R, et al. Localization and regulation of cyclo-oxygenase-1 and -2 and neuronal nitric oxide synthase in mouse spinal cord. Neuroscience 2000; 101: 1093-1108.

31. Eberhart CE, Coffey RJ, Radhika A, Giardiello FM, Ferrenbach S, Dubois RN. Up-regulation of cyclooxygenase 2 gene expression in human colorectal adenomas and adenocarcinomas. Gastroenterology 1994; 107: 1183-1188.

32. Ristimaki A, Honkanen N, Jankala $H$, Sipponen $P$, Harkonen M. Expression of cyclooxygenase-2 in human gastric carcinoma. Cancer Res 1997; 57: 1276-1280.

33. Khan KN, Stanfield KM, Trajkovic D, Knapp DW. Expression of cyclooxygenase-2 in canine renal cell carcinoma. Vet Pathol 2001; 38: 116-119.

34. Mestre JR, Subbaramaiah K, Sacks PG, Schantz SP, Tanabe T, Inoue $\mathrm{H}$, et al. Retinoids suppress epidermal growth factor-induced transcription of cyclooxygenase-2 in human oral squamous carcinoma cells. Cancer Res 1997; 57: 2890-2895.

35. Zhang F, Subbaramaiah K, Altorki N, Dannenberg AJ. Dihydroxy bile acids activate the transcription of cyclooxygenase-2. J Biol Chem 1998; 273: 2424-2428.

36. Agoff SN, Brentnall TA, Crispin DA, Taylor SL, Raaka S, Haggitt RC, et al. The role of cyclooxygenase 2 in ulcerative colitis-associated neoplasia. Am J Pathol 2000; 157: 737-745.

37. McAdam BF, Catella-Lawson F, Mardini IA, Kapoor S, Lawson JA, FitzGerald GA. Systemic biosynthesis of prostacyclin by cyclooxygenase (COX)-2: the human pharmacology of a selective inhibitor of COX-2. Proc Natl Acad Sci USA 1999; 96: 272-277.

38. Mitchell JA, Evans TW. Cyclooxygenase-2 as a therapeutic target. Inflamm Res 1998; 47 (Suppl 2): S88-S92. 